InOedia $\quad \begin{aligned} & \text { InMedia } \\ & \text { The French Journal of Media Studies }\end{aligned}$

9.1. $\mid 2021$

Film and TV-induced Tourism: Some Contemporary

Aspects and Perspectives

\title{
Local Aspects and Impacts of Film-induced Tourism
}

Introducing Three Interviews with Local Tourism Stakeholders

Nathalie Dupont

(2) OpenEdition

Journals

Electronic version

URL: https://journals.openedition.org/inmedia/3027

DOI: 10.4000/inmedia.3027

ISSN: 2259-4728

Publisher

Center for Research on the English-Speaking World (CREW)

\section{Electronic reference}

Nathalie Dupont, "Local Aspects and Impacts of Film-induced Tourism", InMedia [Online], 9.1. | 2021,

Online since 15 January 2022, connection on 08 February 2022. URL: http://journals.openedition.org/ inmedia/3027 ; DOI: https://doi.org/10.4000/inmedia.3027

This text was automatically generated on 8 February 2022.

(c) InMedia 


\title{
Local Aspects and Impacts of Film- induced Tourism
}

\author{
Introducing Three Interviews with Local Tourism Stakeholders
}

Nathalie Dupont

1 In The Experiences of Film Location Tourists, Stefan Roesch mentioned that "film tourism is a specific pattern of tourism that drives visitors to see screened places during or after the production of a feature film or a television production." ${ }^{1}$ This trend has now definitely been taken up by different national and local tourism industries: California, home to many Hollywood studios, has of course its own specific internet page dedicated to film/TV tourism, ${ }^{2}$ and VisitBritain, which had notably highlighted many Harry Potterthemed destinations, now focusses on Back to Bridgerton-11 filming Locations From the Hit Show. ${ }^{3}$ Discover Northern Ireland has been surfing on the worldwide success of Game of Thrones ${ }^{4}$ while New Zealand, which welcomed the famed shooting of The Lord of the Rings trilogy, devotes one section to film tourism on Tourism New Zealand. ${ }^{5}$

2 Films and TV series also generate their own dedicated tourism activities, whether it be on their official sites ${ }^{6}$ or through private companies' like City Breaker's still active $D a$ Vinci Code-themed tour. ${ }^{7}$ France is a rather late comer to the full panoply of filminduced tourism as the law facilitating hosting foreign runaway productions on its territory was only voted in 2009. ${ }^{8}$ Since then Dunkirk (Christopher Nolan, 2017), Fantastic Beasts: The Crimes of Grindelwald (David Yates, 2018), Inception (Christopher Nolan, 2010), M:I - Impossible - Fallout (Christopher McQuarrie, 2018), Sherlock Holmes: A Game of Shadows (Guy Ritchie, 2011), Thor (Keneth Branagh, 2011), Wonder Woman (Patty Jenkins, 2017) and the TV series Merlin (Shine and BBC Wales, 2008-2012) were among the big-budget productions that have benefited from the enticing French tax rebate. ${ }^{9}$

3 As studied by several academics ${ }^{10}$ across a variety of disciplines (for example film studies, economics, geography, adaptation studies, etc.), national legislature's passage of such tax rebates is expected to reap benefits during and after the shooting of films and TV series on their territories. Film/TV-induced tourism is one of the expected benefits, which has been catalogued into nine different forms, according to Busby and Klug: ${ }^{11}$ 


\begin{tabular}{|c|c|}
\hline Form & Characteristic \\
\hline $\begin{array}{l}\text { Film location as an } \\
\text { attraction in its own } \\
\text { right (Evans, ref. 5; Tooke } \\
\text { and Baker; } \\
\text { ref. 6; Riley, ref. 7) }\end{array}$ & $\begin{array}{l}\text { In some cases, movie locations were not considered to be tourism } \\
\text { destinations until they were seen on screen (The Full Monty and } \\
\text { Sheffield), while others were already perceived as attractive } \\
\text { destinations (Riley, et al., ref. 4) }\end{array}$ \\
\hline $\begin{array}{l}\text { Movie tourism as part of } \\
\text { a main holiday (Evans, } \\
\text { ref. 5) }\end{array}$ & $\begin{array}{l}\text { Some tourists will visit a TV or film location or book a film tour while } \\
\text { on holiday without any previous knowledge of the location (Evans, ref. } \\
\text { 5) }\end{array}$ \\
\hline $\begin{array}{l}\text { Movie tourism occurring } \\
\text { as the sole and main } \\
\text { purpose out of special } \\
\text { interest (Evans, ref. } 5 \text { ) }\end{array}$ & $\begin{array}{l}\text { The booking of a holiday to a special destination as a direct result of its } \\
\text { profile on TV (Evans, ref. 5) }\end{array}$ \\
\hline $\begin{array}{l}\text { Movie tourism packages } \\
\text { created by the private } \\
\text { sector (Evans, ref. } 5 \text { ) }\end{array}$ & $\begin{array}{l}\text { Coach companies and tour operators set up packages such as } \\
\text { "Heartbeat Holidays" and "Peak Practice Breaks" (Evans, ref. 5) }\end{array}$ \\
\hline $\begin{array}{l}\text { Movie tourism icons for } \\
\text { tourists to gaze upon as } \\
\text { focal points for visitation } \\
\text { (Riley et al., ref. 4) }\end{array}$ & $\begin{array}{l}\text { Natural scenery, historical background, storyline themes, actors, } \\
\text { symbolic content, and human relationships can serve as icons and } \\
\text { "hallmark events" for movie tourism (Riley et al., ref. 4) }\end{array}$ \\
\hline $\begin{array}{l}\text { Movie tourism to places } \\
\text { where the filming is only } \\
\text { believed to have taken } \\
\text { place (Tooke and Baker, } \\
\text { ref. 6) }\end{array}$ & $\begin{array}{l}\text { Visitors go to the places represented even if the film was shot in a } \\
\text { different setting. The fact that the place filmed is not in every case the } \\
\text { place represented does raise questions about illusion, reality, and } \\
\text { authenticity in the context of what visitors are expected to see and why } \\
\text { (Pocock, ref } 40 \text {; Herbert, ref. 25; Tooke and Baker, ref. 6; Tetley, ref. 1; } \\
\text { Busby and Hambly, ref. 20) }\end{array}$ \\
\hline $\begin{array}{l}\text { Movie tourism as part of } \\
\text { the romantic } \\
\text { gaze (adapted from Urry } \\
1990 \text {, ref. } 37 \text { ) }\end{array}$ & $\begin{array}{l}\text { The romantic tourist likes to gaze on places which have been } \\
\text { constructed and reinforced by TV and film in solitude and privacy, } \\
\text { establishing a semi-spiritual relationship with the place (Urry 1990, ref. } \\
\text { 37) }\end{array}$ \\
\hline $\begin{array}{l}\text { Movie tourism for } \\
\text { reasons of pilgrimage, } \\
\text { nostalgia, and escape } \\
\text { (Riley and Van Doren, } \\
\text { ref. 14) }\end{array}$ & $\begin{array}{l}\text { Movie tourism elevates the consumer beyond the mundane reality of } \\
\text { everyday life (Tresidder, ref. 72). The movie sites of the films Field of } \\
\text { Dreams and Steel Magnolias became pilgrimage points in their own right. } \\
\text { In the case of the latter example, the notion of escape was taken } \\
\text { literally by some as some visitors imitated the storyline by committing } \\
\text { suicide (Riley and Van Doren, ref. 14) }\end{array}$ \\
\hline 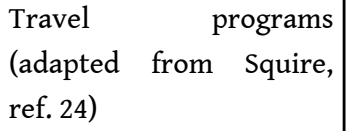 & $\begin{array}{l}\text { A vehicle through which places and people have been reinterpreted and } \\
\text { communicated to wider audiences (Squire, ref. 24) }\end{array}$ \\
\hline
\end{tabular}


This section presents some of these forms through three interviews with "involved tourism stakeholders" ${ }^{\prime 2}$ taking about different local aspects and impacts of filminduced tourism.

5 The interview "Dunkerque and Dunkirk," which can be said to embody the first four forms of Busby and Klug's classification, highlights the now widespread example of the impact of the "placement of destinations in movies and its influence on tourism"13 through the case of Dunkirk (Christopher Nolan, 2017), a film that benefited from the French tax rebate and led to a case study by the $\mathrm{CNC} .{ }^{14}$ In this interview derived from the 2018 day-conference on Tourism, Film and TV Series, ${ }^{15}$ Jean-Yves Frémont, town councilor in employment, economic development and tourism, and Sabine l'Hermet, director of Dunkerque tourist office, detail how the locally-shot American blockbuster ${ }^{16}$ points to the link between the film industry and the role of tourism in local and regional development, notably for the French Hauts-de-France territory and the city where those historical events took place.

In the "Bayeux and the Game of Thrones ${ }^{\circledast}$ tapestry" interview, which can be related to the fourth and fifth forms defined by Busby and Klug, ${ }^{17}$ Fanny Garbe, head of advertising and communication at the French Bayeux Museum, and Séverine Lecart, consumer marketing manager at Tourism Ireland, explain how Bayeux came to benefit from the television series' Bayeux-inspired tapestry. The now famous Game of Thrones ${ }^{\otimes}$ television series has no physical links to Bayeux nor its surrounding area. But its subsequent Bayeux-inspired tapestry came to be exhibited in Bayeux as its layout visually echoes its 'ancestor's' depiction of the conquest of England in 1066 by the Duke of Normandy. Commissioned by HBO and Tourism Ireland, the Game of Thrones ${ }^{\oplus}$ tapestry has thus a narrative and visual link to Bayeux and is another example of the impact film/TV-induced tourism can have on regional economic development.

7 Finally, film/TV-induced tourism can also be linked to festivals, which can be related to the third and ninth forms described in Busby and Klug's classification. Derived from the exchange also held at the 2018 day-conference on Tourism, Film and TV Series, the interview with Karina Hocquette, education, and audience-development manager for the Series Mania festival, underlines the festival's impact on the French Hauts-deFrance territory. The city of Lille in Northern France has in fact been hosting Séries Mania ${ }^{18}$ since 2018 with different Séries Mania-labelled events and performances linked to the best international television series. It has subsequently led to a Series-Mania impact on the tourism industry for the Hauts-de-France region.

\section{NOTES}

1. Stefan Roesch, The Experiences of Film Location Tourists (Bristol: Channel View Publications, 2009), 6 .

2. Visit California homepage. https://www.visitcalifornia.com/road-trips/movie-locations-tour/ $<$ accessed on January 12, 2022>. 
3. "Back to Bridgerton - 11 filming locations from the hit show," Visit Britain. https:// www.visitbritain.com/gb/en/bridgerton-11-filming-locations-hit-show <accessed on January 12, 2022>.

4. "Game of Thrones," Discover Northern Ireland. https://discovernorthernireland.com/things-todo/tv-and-film/game-of-thrones <accessed on November 23, 2021>.

5. "Film Tourism," Tourism New Zealand. https://www.tourismnewzealand.com/marketsinsights/sectors/film-tourism/ <accessed on January 12,2022>.

6. See for example https://www.wbstudiotour.co.uk or https:// www.gameofthronesstudiotour.com <accessed on January 12, 2022>.

7. «Suivez les traces du Da Vinci Code au cœur de paris », City Breaker. https://city-breaker.com/ da-vinci-code-paris/ <accessed on January 12, 2022>.

8. Different modifications were then added. CNC, Crédit d'impôt international, https:// www.cnc.fr/professionnels/aides-et-financements/multi-sectoriel/production/credit-dimpot-

international_778354 <accessed on November 29, 2021> and "Aperçu du système français de crédits d'impôts pour la production cinématographique et audiovisuelle, http://enter-law.com/ french-tax-credit-for-film-and-tv-production/?lang=fr <accessed on November 30, 2021>.

9. Variety Staff, "France, Capital of Film, Provides $30 \%$ Rebate to Foreign Producers," Variety.com. https://variety.com/2018/artisans/production/france-production-incentives-2-1202666453/ $<$ accessed on January 11, 2022>.

10. For more on this, see for example the works of Sue Beeton, Kerry Seagrave Daniel Steinhart and Janet Wasko.

11. Busby, G. and Klug, J., "Movie-induced Tourism: The Challenge of Measurement and Other Issues," Journal of Vacation Marketing 7, no. 4 (October 2001): 318.

12. Roesch, The Experiences of Film Location Tourists, 14.

13. Simon Hudson and J.R. Brent Ritchie, "Promoting Destinations via Film Tourism: An Empirical Identification of Supporting Marketing Initiatives," Journal of Travel Research 44, (May 2006): 387-396. https://www.researchgate.net/publication/

237807231_Promoting_Destinations_via_Film_Tourism_An_Empirical_Identification_of_Supporting_Marketing_Initiatives $<$ accessed on April 24, 2021>.

14. $\mathrm{CNC}$, "L'impact des tournages sur le tourisme," and "Cinéma et tourisme font bon ménage à Dunkerque," CNC, https://www.cnc.fr/cinema/etudes-et-rapports/etudes-prospectives/limpactdes-tournages-sur-le-tourisme_227677 and https://www.cnc.fr/cinema/actualites/cinema-ettourisme-font-bon-menage-a-dunkerque_44888 < both accessed on January 11, 2022>.

15. Sarah Kelley, “Tourism, Cinema and TV Series Conference," Transatlantica 2, (2018). https:// journals.openedition.org/transatlantica/13571 <accessed on June 30, 2021>.

16. The film sheds light on Operation Dynamo during which the allied troops were evacuated from the French city of Dunkerque in 1940.

17. Busby and Klug, "Movie-induced Tourism: The Challenge of Measurement and Other Issues," 318.

18. The festival presents itself as "the biggest European event entirely dedicated to television series in Europe," Series Mania. https://seriesmania.com <accessed on June 9, 2021>. 


\section{AUTHOR}

\section{NATHALIE DUPONT}

Nathalie Dupont is Associate professor of American studies at the University du Littoral Côte d'Opale (ULCO). Her research focuses on the contemporary films produced by American studios, and what those films tell us about American society. It also focuses on the links between Hollywood and American Christians. She has published several articles on those subjects, as well as Between Hollywood and Godlywood: the Case of Walden Media (Peter Lang, London, 2015). She is a co-founder of CinEcoSA (https://www.cinecosa.com) and co-organizer of several of its conferences. 